DOI: $\underline{10.20472 / E S .2019 .8 .1 .007 ~}$

\title{
WOMEN'S PARTICIPATION IN THE LABOR MARKET AND ECONOMIC DEVELOPMENT: EVIDENCE FROM ECCAS AND ECOWAS COUNTRIES
}

\author{
URSULA-CHRISTIANE OUAÏMON , YABIN ZHANG
}

\begin{abstract}
:
This paper examines the relationship between women's participation in the labor market and economic development in ECCAS and ECOWAS over the period 2006-2015 by using dynamic panel data model. The analysis is run from two different perspectives - on one hand, the relationship is investigated for a sample of 24 countries; and on the other hand - the evidence is disaggregated and the relationship is re-examined with two regional blocs (ECCAS, ECOWAS). The OLS, fixed effects model, instrumental IV and the generalized method of moments (GMM) estimator developed by Arellano and Bond (1991) are employed to evaluate and account for dynamic effects. The main results show that there is a U-shaped relationship between female labor force participation and the economic development for the encompassing 24 countries. The findings are important for ECCAS and ECOWAS countries policy makers to undertake effective policies that can boost female labor force participation and enhance economic growth in their countries.
\end{abstract}

\section{Keywords:}

Female labor force participation; economic development; panel data model; ECCAS; ECOWAS.

JEL Classification: C36, J21, 011

\section{Authors:}

URSULA-CHRISTIANE OUAÏMON , Hunan University , China, Email: christianegondje@yahoo.com YABIN ZHANG, Hunan University, China, Email: yabinzhang@hnu.edu.cn

\section{Citation:}

URSULA-CHRISTIANE OUAÏMON, YABIN ZHANG (2019). Women's participation in the labor market and Economic Development: Evidence from ECCAS and ECOWAS Countries. International Journal of Economic Sciences, Vol. VIII(1), pp. 94-105., 10.20472/ES.2019.8.1.007 


\section{Introduction}

The economic and social development refers to all the positive changes (technical, demographic, social, health ...) that can be experienced in a geographical area (world, continent, country, region ...).

The African countries' leaders have agreed to establish the regional economic zones, economic communities with a view to promote and strengthen harmonious cooperation, balanced and selfsustaining development in the fields of economic and social activities.

Africa's Regional Economic Communities (RECs) include eight sub regional bodies which are the building blocks of the African Economic Community established in the 1991 Abuja Treaty which provides the overarching framework for continental economic integration. There are : (i) The Arab Maghreb Union (AMU/UMA), (ii) The Economic Community of West African States (ECOWAS), (iii) The East African Community (EAC), (iv) The Intergovernmental Authority on Development (IGAD), (v) The Southern African Development Community (SADC), (vi) The Common Market for Eastern and Southern Africa (COMESA), (vii) The Economic Community of Central African States (ECCAS), and (viii) The Community of Sahel-Saharan States (CENSAD).

The ECCAS was created in October 1983 and currently has eleven member states namely Angola, Burundi, Cameroon, Central African Republic, Congo, Gabon, Equatorial Guinea, the Democratic Republic of Congo, Rwanda, Sao Tome \& Principe, and Chad. With a population estimated to be 145 million by 2013 and spread over an area of 6,640,490 km2, the region is favorable for investment and business development. For more than a decade, the economic activity of the region is among the most dynamic of the continent, with average growth around $5 \%$ over the last five years. A performance certainly attributable to soaring commodity prices, but also to macroeconomic stability and the implementation of good policies that have helped support growth.

The ECOWAS is a West African intergovernmental organization which was created in May 1975. Currently, this block has sixteen member states namely: Benin, Burkina-Faso, Cape-Verde, Côte d'Ivoire, The Gambia, Ghana, Guinea, Guinea-Bissau, Liberia, Mali, Niger, Nigeria, Senegal, Sierra Leone and Togo. It's main objective is to promote cooperation and integration in the perspective of a West African Economic Union with a view to raising the standard of living of its people, maintaining and increasing economic stability to strengthen relationship between member States and contribute to the progress and development of the African continent. ECOWAS covers an area of $5,114,240 \mathrm{~km} 2$ and a population of 347 million in 2015. The overall GDP of ECOWAS member States is US\$817.04 billion, making it the 20th economic power of the world.

The economic development requires the creation of wealth through men and women labor force participation. Women labor participation in the workforce is good for growth and development. The educated women would help offset the shrinking labor force, boost growth potential in the medium term, and raise living standards for all population. The participation of women in the labor market in Africa is very low compared to other continents. However, there is a clear positive trend in the participation of women in decision-making positions in the last ten years. 
In most of ECCAS and ECOWAS countries, women's participation in the labor market has increased significantly in recent decades. Below is the graph showing women participation in the labor market for both ECCAS and ECOWAS countries for the period from 1995 to 2015.

\section{Figure 1. Participation in the labor market of women aged 15+ in ECCAS and ECOWAS countries.}

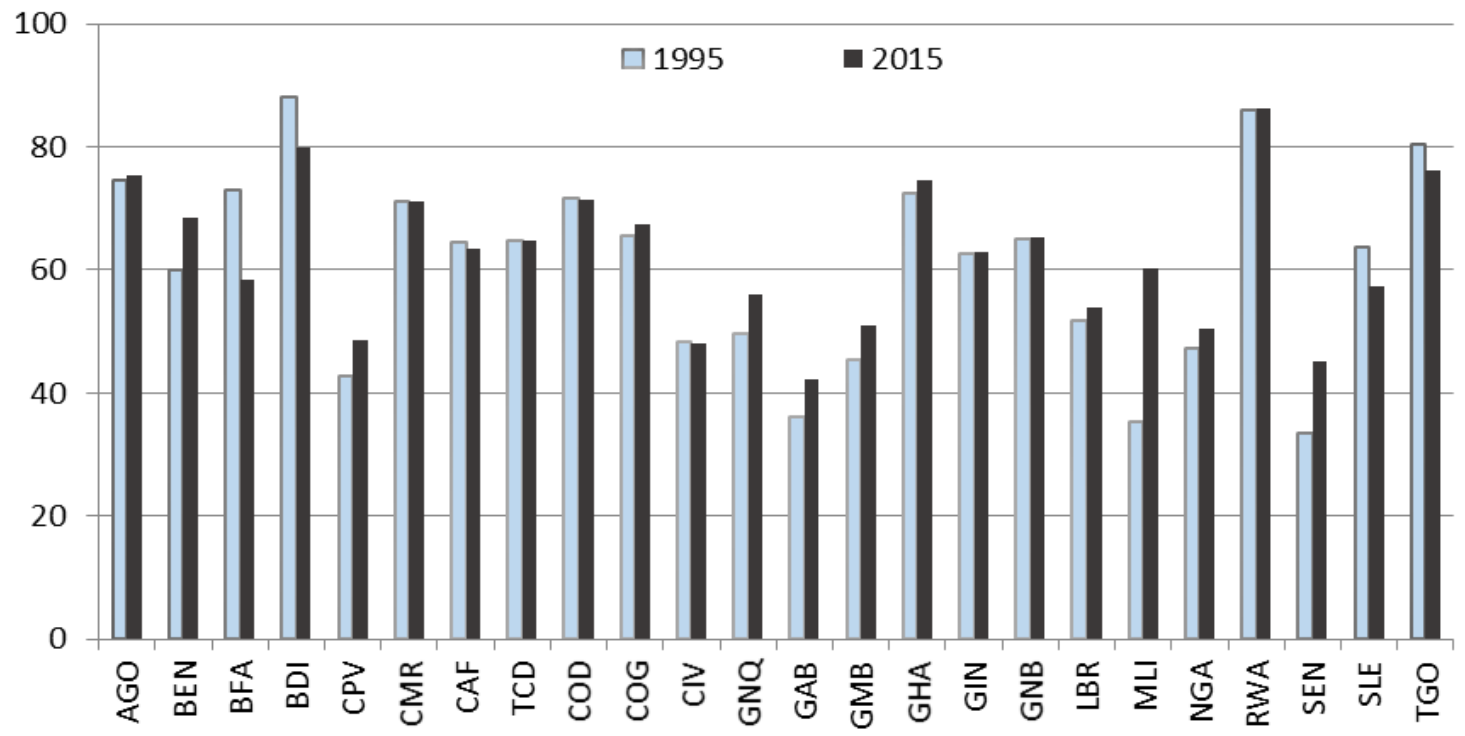

Source: World Bank's World, own calculations and processing.

The level of women's participation remains very variable between countries. For women of very active age, their participation rate ranges from values of $65 \%$ or less in Benin, Cape-Verde, Côte d'Ivoire, Central African Republic, Congo, Gabon, Gambia, Guinea, Liberia, Mali, Nigeria, Senegal, Chad and Sierra Leone. The values are well above $65 \%$ in countries such as Angola, Burkina-Faso, Burundi, Cameroon, The Democratic Republic of Congo, Ghana, Rwanda and Togo. Women's participation in the labor market is the main factor underlying the increase in overall participation rates and the variation between countries in overall participation rates (Burniaux et al., 2003). The policies and experience of ECCAS and ECOWAS countries in the field of women's participation are very diverse.

The decline in women's economic activity is cause for concern to those who are interested in women's well-being as well as those who believe that women are valuable resources and must be utilized efficiently. Women's employment is an indicator of their overall status in society and also a critical factor in their progression towards economic independence (Mammen and Paxson 2000).

Understanding the relationship between female labor force participation and economic development is important for a variety of reasons. The $\mathrm{U}$-shaped hypothesis describes the correlation of the female labor force participation rate with economic development (structural shifts in economic activity and changes to household labor supply and attitudes about women working outside the home). In its basic form, the hypothesis posits that female participation rates are highest in poor countries, where women are engaged in subsistence activities, and fall in middle-income countries because of the transition of (mainly) men to industrial jobs. As 
education levels improve and fertility rates fall, women are able to join the labor force in response to growing demand in the services sector. This is a stylized fact, but it is not robust to different data sets and econometric methodologies.

The U-shaped hypothesis suggests that there is a short of tradeoff between gender equality and economic growth during a country's development. Studying this relationship is important for academicians and policy makers alike to identify trends in labor force participation and to design and implement policy to that end.

This research fundamentally seeks to examine the relationship between the participation rate of women in the labor market and economic development in ECCAS and ECOWAS countries by testing the U-shaped hypothesis, in two different perspectives - on one hand, the relationship is investigated for a sample of 24 countries of ECCAS and ECOWAS countries; and on the other hand - the evidence is disaggregated and the relationship is re-examined with two regional blocs (ECCAS, ECOWAS), to determine whether the U-shaped hypothesis is revealed only in the set of 24 countries or preferably is held in respective regional blocs.

The analysis focuses on the economically active women aged 15 and over and the significance of his research arises out of the information that dynamic interaction amongst these macroeconomic influences will have a significant impact on policy-making. The originality of this study relies on the fact that it is the first work that investigates the relationship between overall GDP per capita and female labor force participation in ECCAS and ECOWAS using the OLS, fixed effects model and generalized method of moments (GMM) estimator developed by Arellano and Bond (1991).

The structure of this paper is organized as follows: Section 2 presents a brief of literature review, Section 3 gives an overview on the data and describes the methods used in the study, Section 4 presents the results and their discussion and finally, Section 5 presents the conclusion and policy implications.

\section{Literature Review}

The feminization of labor force and the level of economic growth are described by the long-term U-shaped relationship (Sinha, 1965). The U-shaped hypothesis is the prevalent hypothesis about the long-term relationship between economic development and female labor force participation (Boserup, 1970, Durand, 1975; Goldin, 1995, Psacharopoulos and Tzannatos, 1989). This hypothesis states that during the early stages of economic development, female labor force participation declines due to the initial structural changes of the economy and the transition from an agricultural to an industrialized society while it increases in later stages when countries mature into modern economies, fertility rates decline and female education increase.

Cross-country studies have found consistent evidence for the U-shaped hypothesis. Among cross-country studies, (Goldin, 1995) found that the relationship held for a group of about 100 countries in both 1980 and 1985. Mammen and Paxson (2000) followed the work of Goldin's for 1980 and 1985 and extended the test to 1970 and 1975 reaching the same conclusion. Tam (2011) found similar results using panel data for a set of 134 countries from 1950-1980 and by Tsani et al., (2013) for South Mediterranean countries.

Time-series studies also have found evidence for the U-Shaped hypothesis, such as the work of Goldin (1995) that examined time-series data for a study on the US. Female labor force 
participation fell during the early stages of economic growth and rose later as development continued. Similar results were found by a study done by Tilly and Scoot (1987) for England and France, other developed nations. There are fewer studies on developing countries due to a lack of data. Mammen and Paxson (2000) provide some evidence for the U-shaped hypothesis in Thailand and India. Tansel (2002) examined time series evidence on provinces in Turkey and found evidence for the U-Shaped hypothesis.

Gaddis and Kalsen, (2013) found less robust evidence for the U-shaped hypothesis testing both a static (OLS and fixed effects) model and a dynamic (autoregressive) model. This paper used cross-country data from 1980-2005 and found that the results for the U-shaped hypothesis were very sensitive to the data source used.

Verme (2014) divided analysis between parametric and nonparametric evidence using data collected from the International Labor Organization and the World Bank. The researcher's nonparametric evidence showed that the U-shaped hypothesis held both worldwide and within the MENA region itself. The paper suggested that MENA countries are at the turning point of the Ushaped curve, explaining their low female labor force participation rates. The parametric evidence did not hold as strongly though, with some countries in the region showing non-significance or even an inverted U-shape. The paper used a model similar to Gaddis (2013) and also suggested that U-relationship had little relevance for developing countries.

Lechman and Kaur (2015) used 162 world countries over the period 1990-2012. It was hypothesized that an analysis would reveal a U-shaped relationship between female labor force participation and economic growth. The analysis is run from two different perspectives. In the first, the relationship is examined for a sample encompassing 162 countries; and in the second, the evidence is disaggregated and the relationship is re-examined within four income-groups (lowincome, lower-middle-income, upper-middle-income and high-income). The main findings support the hypothesis of the U-shaped relationship between female labor force and economic growth. Moreover, the U-shaped feminization hypothesis was not positively verified in the case of lowincome countries.

Chapman (2015) tested the U-shaped hypothesis using a panel data set of 20 countries in the Middle East and North Africa (MENA) over the period of 1990-2012. The results of this paper verified the U-shaped relationship between economic growth and female labor force participation rates. The MENA region's low female labor force participation rates can be explained in part by their transition towards the bottom of the U-shaped curve.

\section{Data and Methods}

\subsection{Data description}

This study examines the relationship between female labor participation and economic development by testing the U-shaped hypothesis build on Kuznets's thesis suggesting a curvilinear relationship between economic development and female labor participation.

For the curvilinear relationship between economic development and female labor participation, we use the level of GDPPC and square (GDPPC) $)^{2}$ of natural logarithm of gross domestic product per 
capita in the regression equation. We use the natural logarithms of the GDP per capita as proxy of the economic development.

This paper applied balanced panel data of female labor force participation rate and GDP per capita in constant 2010 U.S. dollars as proxy of the economic development from of two panels of selected Africa's regional economic communities, a panel of ten ECCAS countries: Angola, Burundi, Cameroon, Central Africa Republic, Congo, Gabon, Equatorial Guinea, Democratic Republic of Congo, Chad and Rwanda for 2006-2015, and a panel of fourteen ECOWAS countries: Benin, Burkina Faso, Cape-Verde, Côte d'Ivoire, Gambia, Ghana, Guinea, GuineaBissau, Liberia, Mali, Nigeria, Senegal, Sierra Leone and Togo for 2006-2015. These countries are selected based on the availability of data for the period 2006-2015.

The dataset for this study were collected from the World Bank's World Development Indicators database over the period of 2006-2015. Female labor force participation rate (FLFPR) is defined as the proportion of the females aged 15 and older that is economically active. Economic development is controlled for using GDP per capita in constant 2010 U.S. dollars. GDP per capita (GDPPC) is the gross domestic product divided by the midyear population of the country.

The table 1 below show the descriptive statistics of our data.

Table 1. Summary Statistics.

\begin{tabular}{llllll}
\hline Variable & Observations & Mean & Std. Dev. & Minimum & Maximum \\
\hline FLFPR & 240 & 61.784 & 12.389 & 34.26 & 86.243 \\
InGDPPC & 240 & 6.931 & 1.050 & 5.408 & 9.920 \\
\hline
\end{tabular}

Source: World Bank's World, own calculations and processing.

\subsection{Methodology}

The U-shaped relationship between women's labor force participation and economic development was estimated using cross-sectional methods. We use GDP per capita as a proxy for economic development. To test the hypothesis of the U-shaped relationship we apply the following model:

$$
\text { FLFPR }_{i}=\alpha+\beta_{1} \ln G D P P C_{i}+\beta_{2} \ln \left(G D P P C_{i}\right)^{2}+\mu_{i}
$$

where $G D P P C_{i}$ is the gross domestic product per capita for country $i . F L F P R_{i}$ is the female labor force participation rate for country i. GDPPC ${ }_{i}^{2}$ its square of the gross domestic product for country $i$. The U-Shaped hypothesis holds if the estimated coefficients are as follows: $\beta_{1}<0$ and $\beta_{2}>0$. This is a simple cross-country equation and is applied to one point in time in literature.

Using Panel data, our model becomes:

$$
\text { FLFPR }_{i t}=\alpha_{i}+\beta_{1} \ln G D P P C_{i t}+\beta_{2}\left(\ln G D P P C_{i t}\right)^{2}+\mu_{i t}
$$

The model (2) ignores time and country specific effects, but it has been used in the literature to find evidence for the U-Shaped hypothesis. We use the appropriate model fixed effects estimator, which controls for country specific effect. 
FLFPR $_{i t}=\alpha_{i}+\beta_{1} \ln$ SDPPC $_{i t}+\beta_{2}\left(\ln G D P P C_{i t}\right)^{2}+\delta_{t}+\mu_{i t}$

where $\delta_{t}$ is the fixed effects and $\mu_{i t}$ is the error term capturing all other omitted factors, measurement errors and possible misspecifications. This controls for time-invariant, country factors effecting women's participation in the labor market. As estimates generated from the model (3) might not be consistent due to endogeneity of explanatory variables. To overcome this last problem and controlling for endogeneity, one can run a linear dynamic panel data model such as the Arellano-Bond (1991) model estimated with a Generalized Method of the Moments with lagged $\ln G D P P C_{i t}$ and lagged $\ln G D P P C_{i t}^{2}$ as instruments.

$$
F L F P R_{i t}=\alpha_{i}+\beta_{1} \ln G D P P C_{i t}+\beta_{2}\left(\ln G D P P C_{i t}\right)^{2}+\beta_{3}\left(F L F P R_{i,(t-1)}\right)+\mu_{i t}
$$

where $F L F P R_{i,(t-1)}$ is the lagged dependent variable.

\section{Results and discussions}

\subsection{Analysis of the regression for ECCAS and ECOWAS countries sample.}

Table 1 below displays the estimation results based on multiple periods for the ECCAS and ECOWAS countries sample. The outcomes displayed below suggest that female labor participation rate and the gross domestic product per capita are specifically negatively correlated ante vertex of the quadratic curve, while after passing the low point, the examined relationship starts to be positive, and thus the U-shaped patterns are generated. The low peak of the curve for OLS estimates corresponds to InGDPPC $i$ it $=11.45$ which is equivalent to approximately 93901 of GDP per capita (in 2010 constant in US\$).

Table 2. Regression results.

\begin{tabular}{lllll}
\hline Variable & OLS & FE & FE IV & GMM \\
\hline InGDPPC $_{\text {it }}$ & -12.574 & -11.421 & -22.5 & -.753 \\
& $(-1.5)$ & $(-.84)$ & $(-1.65)$ & $(0.01)$ \\
$\left(\text { InGDPPC }_{\text {it }}\right)^{2}$ & .549 & .882 & 1.674 & .066 \\
& $(0.99)$ & $(0.92)$ & $(0.095)$ & $(4.07)$ \\
FLFPR $_{\text {it- }}$ & & & & .879 \\
& & & & $(1884)$ \\
Cons & 121.93 & 97.576 & 135.552 & 9.585 \\
R-squared & $(3.96)$ & $(0.057)$ & $(2.97)$ & $(8.08)$ \\
Arellano-Bond test & .14 & 0.0083 &. & - \\
\hline
\end{tabular}




\begin{tabular}{|c|c|c|c|c|}
\hline \multicolumn{5}{|l|}{ proba $>z$} \\
\hline Instruments & \multicolumn{4}{|c|}{ proda $>2$} \\
\hline $\begin{array}{l}\text { Number } \\
\text { countries }\end{array}$ & 24 & 24 & 24 & 24 \\
\hline Observations & 240 & 240 & 216 & 192 \\
\hline
\end{tabular}

Source: World Bank's World, own calculations and processing.

OLS - Fixed effects regressions: As hypothesized, regardless of the model applied, the regressor InGDPPC $C_{i t}$ always holds a negative sign, and $\left(\text { InGDPPC }_{i t}\right)^{2}$ holds a positive one. The previous allows for drawing a more general conclusion that the female labor participation and economic growth relationship follows the U-shaped pattern over the period in scope. The analysis is based on panel data, thus the evidence demonstrates evolution of changing participation of female labor supply (in total labor) which is attributed to economic growth. The downward slope of the curve demonstrates the de-feminization process of the labor force which goes along with economic growth. Structural changes are characteristic for countries located in early stages for growth, as women (usually unskilled) with quite low-paid jobs join the education system instead. Conversely, the upward slope explains growth in women's agency and empowerment across countries which are accompanied by economic growth. Observed positive changes in women's labor market empowerment are probably becoming a permanent characteristic rather than mere cyclical change.

Using within estimator, the coefficients $\beta_{1}$ and $\beta_{2}$, explaining mediated effects of InGDPPC $C_{\text {it }}$ on FLFPR $_{\text {it }}$ due to cross-country differences. In each case $\beta_{1}$ tends to be higher than $\beta_{2}$. It might suggest that the negative relationship between FLFPR ${ }_{\text {it }}$ and GDPPC $_{\text {it }}$ is dominant and far better established with respect to this relationship. However, bearing in mind that the static estimations especially OLS may be heavily biased, we additionally account for dynamic effects using the Arellano-Bond estimators. The major advantage of using the GMM estimator compared to simple OLS, is that it allows for endogeneity of the two GDPPC $_{\text {it }}$ variables included in the model. To ensure the validity of our estimations we first perform the estimations starting with the secondorder lags, and using a respective diagnostic test we accept or reject the estimation (we accept the estimation under rigid assumption that for the first order correlation the $p<.05$; but - for the second-order autocorrelation the $p>.05$; which allows for not rejecting the validity of instruments used). Henceforth, we estimate the dynamic panel model, including first lag of the response variable. After applying the GMM estimator the U-shaped FLFPR it versus GDPPC interdependency has vanished, while exclusively the $\beta 3$ coefficient - explaining the "dynamic effect' - demonstrates statistical significance. Put another way, the $U$ vanished when using the dynamic estimates and the FLFPR it $_{\text {versus }}$ GDPPC $_{\text {it }}$ relationship is not held.

\subsection{Analysis of the regression for ECCAS countries sample.}

In the following section, we aim to re-examine the U-shaped feminization hypothesis and test,

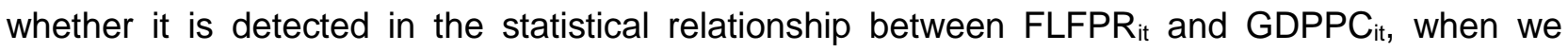
deliberately disaggregate the evidence and report on analogue relationship is two groups. To this aim we split the original sample into two parts. Henceforth, we test the U-shaped feminization hypothesis for two groups such ECCAS (10 countries) and ECOWAS (14 countries). 
We examine the U-shaped relationship for ECCAS countries. The outcomes displays in table 3 below that the relationship follows a rather inverted $U$ pattern, thus the $U$-feminization hypothesis is not confirmed. The regression results for ECCAS countries do not confirm the U-Shaped hypothesis. Only the FE IV estimations generate the correct parameters sign. While when estimating the regression applying OLS $\left(\beta_{1}=14.88\right.$ and $\left.\beta_{2}=-1.382\right)$ and $\mathrm{FE}\left(\beta_{1}=2.677\right.$ and $\beta_{2}=-$ .1006). The existence of the inverted $U$-shaped relationship between female labor force participation and economic growth (compare OLS results), suggests that in a vast majority of countries over 2006-2015, the positive relationship between FLFPR $R_{\text {it }}$ and GDPPC $_{\text {it }}$ is dominant $\left(\beta_{1}=14.88\right.$ and $\left.\beta_{2}=-1.382\right)$ over the negative one. Important to note that OLS, FE and FE IV resulted in statistical insignificance. This can be explained by the current state of socio-economic development, various political and religious regimes, or for example, legal and institutional solutions; which substantially impact the way female labor force participation and economic growth are interdependent in the long-term perspective. To test for potential dynamic effects, we estimate the dynamic panel model, including first lag of the response variable. Applying the GMM estimator, the U-Shaped FLFPR it $_{\text {versus }}$ GDPPC $_{\text {it, }}$ interdependency vanishes, while exclusively the $\beta_{3}$ coefficient - explaining the 'dynamic effect' - results in statistical significance.

Table 3. Regression results for ECCAS countries.

\begin{tabular}{|c|c|c|c|c|}
\hline Variable & OLS & FE & FE IV & GMM \\
\hline $\operatorname{lnGDPPC}_{\mathrm{it}}$ & $\begin{array}{l}14.88 \\
(1.86)\end{array}$ & $\begin{array}{l}2.677 \\
(.084)\end{array}$ & $\begin{array}{l}-.516 \\
(-0.11)\end{array}$ & $\begin{array}{l}2.459 \\
(1.69)\end{array}$ \\
\hline$\left(\ln G D P P C_{i t}\right)^{2}$ & $\begin{array}{l}-1.382 \\
(-2.61)\end{array}$ & $\begin{array}{l}-.1006 \\
(-0.44)\end{array}$ & $\begin{array}{l}.120 \\
(0.35)\end{array}$ & $\begin{array}{l}-.159 \\
(-1.59)\end{array}$ \\
\hline FLFPR $_{\text {it-1 }}$ & & & & $\begin{array}{l}.935 \\
(18.15)\end{array}$ \\
\hline Cons & $\begin{array}{l}34.894 \\
(1.18)\end{array}$ & $\begin{array}{l}53.58 \\
(4.81)\end{array}$ & $\begin{array}{l}64.743 \\
(4.10)\end{array}$ & $\begin{array}{l}-4.873 \\
(-0.91)\end{array}$ \\
\hline R-squared & .48 & $\begin{array}{l}0.05 \\
\text { (within) }\end{array}$ & $\begin{array}{l}0.02 \\
\text { (within) }\end{array}$ & - \\
\hline $\begin{array}{l}\text { Arellano-Bond test } \\
\text { proba }>z\end{array}$ & & & & .000 \\
\hline Instruments & No & No & Yes & Yes \\
\hline $\begin{array}{l}\text { Number } \\
\text { countries }\end{array}$ & 10 & 10 & 10 & 10 \\
\hline Observations & 100 & 100 & 90 & 80 \\
\hline
\end{tabular}

Source: World Bank's World, own calculations and processing.

The regressions (FE and FE IV) demonstrate worse fits while for FE the R-within is 0.05 and for FE IV the R-within is 0.02 . 
Many countries in ECCAS are low-income countries and the level of women's participation rate ranges from values of $65 \%$ or less. ECCAS countries need to implement a strong policy to improve the female labor force participation and boost the growth economic.

\subsection{Analysis of the regression for ECOWAS countries sample.}

Regarding the ECOWAS countries, the expected U-shaped pattern is inversed and the OLS estimations are statistically insignificant. Turning the results of the estimated FE and FE IV models, both $\beta_{1}$ and $\beta_{2}$ parameters are statistically significant and they carry the 'correct' signs. In case of ECOWAS countries, the existence of the inverted U-shaped relationship between female labor force participation and economic growth (compare OLS results), suggests that in a vast majority of countries over 2006-2015, the positive relationship between FLFPR $R_{i t}$ and GDPPC $_{\text {it }}$ is dominant $\left(\beta_{1}=43.88\right.$ and $\left.\beta_{2}=-3.564\right)$ over the negative one.

Table 4. Regression results for ECOWAS countries.

\begin{tabular}{|c|c|c|c|c|}
\hline Variable & OLS & FE & FE IV & GMM \\
\hline \multirow{2}{*}{ InGDPPC ${ }_{i t}$} & 43.88 & -66.789 & -82.747 & -5.542 \\
\hline & $(1.58)$ & $(-2.48)$ & $(-2.49)$ & $(-1.04)$ \\
\hline \multirow{2}{*}{$\left(\operatorname{lnGDPPC} C_{i t}\right)^{2}$} & -3.564 & 4.939 & 6.093 & .409 \\
\hline & $(-1.79)$ & $(2.48)$ & $(2.46)$ & $(1.03)$ \\
\hline \multirow{2}{*}{ FLFPR $_{\mathrm{it}-1}$} & & & & .878 \\
\hline & & & & (80.82) \\
\hline \multirow{2}{*}{ Cons } & -74.92 & 281.475 & 336.29 & 25.826 \\
\hline & $(-0.78)$ & (3.09) & (3.02) & $(1.45)$ \\
\hline \multirow[t]{2}{*}{ R-squared } & .13 & 0.047 & 0.042 & - \\
\hline & & (within) & (within) & \\
\hline Arellano-Bond test & & & & .000 \\
\hline \multicolumn{5}{|l|}{ proba $>z$} \\
\hline Instruments & No & No & Yes & Yes \\
\hline Number of countries & 14 & 14 & 14 & 14 \\
\hline Observations & 140 & 140 & 126 & 112 \\
\hline
\end{tabular}

Source: World Bank's World, own calculations and processing.

The ECOWAS countries relatively worse fits of the FE and FE IV models, while for FE the Rwithin is 0.047 and for FE IV the R-within is 0.042 .

To test for potential dynamic effects, we estimate the dynamic panel model including first lag of the response variable. Applying the GMM estimator the U-shaped FLFPR $R_{\text {it }}$ versus GDPPC $_{\text {it }}$ interdependency vanished, while exclusively the $\beta_{3}$ coefficient-explaining the 'dynamic effect' results in statistical significance. 


\section{Conclusions and Policy Implications}

This paper examined the evidence on the U-Shaped relationship between female labor force participation and economic development in 24 ECCAS and ECOWAS countries over the period 2006-2015 by using the OLS, fixed effect, instrumental IV and the generalized method of moment (GMM). The empirical results showed the $U$-shaped hypothesis is verified in all countries (ECCAS and ECOWAS) for the different models and in sub-group samples both ECCAS and ECOWAS. In the results, only FE IV results present that U-shaped hypothesis is valid in ECCAS countries. In ECOWAS countries the results of fixed effects, instrumental IV and GMM confirm the validity of ushaped hypothesis.

The governments and decision makers should embrace reforms on social norms and cultures that circumscribe the extent to which it is possible or desirable for women to enter the labor force. Countries with economies that are strongly service-oriented, by definition, create more favorable conditions for increasing female labor force participation. Moreover, some country-specific characteristics, for instance, religion, language, culture, social attitudes, level of education, and human capital determine the strength and the nature of the examined relationships. Social barriers affecting female labor supply operate differently in different contexts. In particular, income levels and macroeconomic variables play an important role. As our empirical results showed above, there is a U-shaped relationship between GDP per capita and female labor force participation.

It is highly recommended that further research in this area should lay more emphasis on considering incorporating more variables which would enable better explanation of reasons for the low level of female labor force participation rate in ECCAS and ECOWAS countries.

\section{References}

Arellano, M. and Bond, S., (1991). Some tests of specification for panel data: Monte Carlo evidence and an application to employment equations. The Review of Economic Studies, 58(2), pp.277-297. https://doi.org/10.2307/2297968

Burniaux, J.M. Duval, R. and Lee, Jaumotte, F. (2003). "Coping with ageing: a dynamic approach to quantify the impact of alternative policy options on future labour supply in OECD countries", Economics Department Working Papers No.371, OECD.

Boserup, E., (1970). Women's Role in Economic Devleopment. New York: St Martin's Press.

Chapman A. K. (2015). Economic Development and Female Labor Force Participation in the Middle East and North Africa: A test of the U-Shape Hypothesis. Gettysburg Economic Review.

Durand, J.D (1975). The Labor Force in Economic Development, Princeton: Princeton University Press.

Gaddis, I and Klasen S. (2013). Economic Development, Structural Change and Women's Labor Force Participation: A Reexamination of the Feminization U Hypothesis. Journal of Population Economics. https://doi.org/10.1007/s00148-013-0488-2

Goldin, C. (1995). The U-Shaped Female Labor Force Function in Economic Development and Economic History. Investment in Women's Human Capital and Economic Development, University of Chicago Press. https://doi.org/10.3386/w4707 
Kottis, A.P (1990). Shifts over time and regional variation in women's labor force participation rates in a developing economy. Journal of Development Economics, 33, 117-132. https://doi.org/10.1016/03043878(90)90009-Z

Lechman, E. and Kaur, H. (2015). Economic Growth and Female Labor Participation - verifying the UFeminization Hypothesis. New evidence from 162 countries over the period 1990-2012. Economics and Sociology, Vol.2, No1, pp 246-257. DOI: 10.14254/2071- 789X.2015/8-1/19

Mammen, K. and Paxson, C. (2000). Women's Work and Economic Development. Journal of Economic Perspectives 14 (Autumn): 141-64. https://doi.org/10.1257/jep.14.4.141

Psacharopouplos, G. and Tzannatos, Z. (1989). Female Labor Force Participation: An International Perspective. The World Bank Research Observer, 4, 187-202. https://doi.org/10.1093/wbro/4.2.187

Sinha, J.N., (1965). Dynamics of female participation in economic activity in a developing economy. In World Population Conference, Belgrade (Vol. 4).

Tam, H. (2011). U-shaped female labor participation with economic development: Some panel data evidence. Economics Letters, 110(2), 140-142. https://doi.org/10.1016/j.econlet.2010.11.003

Tansel, A. (2002). Economic development and female labor force participation in Turkey: Time-series evidence and cross-section estimates. https://doi.org/10.2139/ssrn.301946

Tilly, A. and Scott, J. 1987. Women, Work, and Family, Routledge, New York.

Tsani, S., Paroussos, L., Fragiadakis, C., Charalambidis, I., \& Capros, P. (2013). Female labour force participation and economic growth in the South Mediterranean countries. Economics Letters, 120(2), 323-328. https://doi.org/10.1016/j.econlet.2013.04.043

Verme, P. (2014). Economic Development and Female Labor Participation in the Middle East and North Africa - A Test of the U-shape Hypothesis. Policy Research Working Papers. The World Bank. https://doi.org/10.1596/1813-9450-6927 